\title{
THE COTTAGE INDUSTRY OF MUSIC INSTRUMENT MAKING - AESTHETIC AND EXPRESSIONS IN CREATIVE MUSIC WORKS
}

\author{
ABDUL JAMAL ABD HAMID*
}

\begin{abstract}
Abstrak
Kreativiti dalam proses pembuatan alat muzik merangkumi aspek daya imaginasi dari pemikiran asal, ekspresi seni dan budaya, sensitif kepada nilai estetik dan pemerhatian kontekstual. Kepentingan elemenelemen ini menyumbang kepada struktur pembuatan alat muzik yang dapat diterima berdasarkan nilai kualiti estetik dan kepentingan filosofikal selain dari keperluan nilai komersil. Dalam pasaran komersil, kajian ini telah merumuskan bahawa ketiadaan produk instrument muzik buatan tempatan memerlukan tindakan susulan dari institusi dan organisasi yang berkaitan. Tulisan ini juga mengupas aktiviti kreatif pembuatan alat muzik yang dapat dijadikan wahana untuk mempromosi dan mengarusperdanakan industri muzik dalam penjanaan ekonomi kreatif Negara.
\end{abstract}

Kata Kunci: Industri Desa, Kreativiti dan Estitika, Keusahawanan

\begin{abstract}
Creativity in music instrument making involves the notion of 'imagination' from original thoughts, expression of the art and culture, aesthetic sensitivity and contextual awareness. These are vital elements of associations contributing to the structure of music instrument making which can be perceived not just through its commercial preferences but also through its aesthetic qualities or philosophical significance. Along the commercial lines, findings have concluded that the absence of 'local-made' music instrument products in Malaysian music outlets, which consequently highly dependable on imported products, are an insights to be addressed by both related institutions and relevant authorities. This paper too explore some inspiring creative activities in the cottage industry of music instrument making that serves to propagate and to promote the music industry as a distinctive opportunity and avenue in generating the nation's creative economy
\end{abstract}

Keywords: Cottage Industry, Creativity and Aesthetic, Commercialization

* Profesor di Fakulti Teknologi Kreatif \& Warisan, Universiti Malaysia Kelantan (UMK) 


\subsection{Introduction}

Creativity is an integral in the mastery of music craftsmanship process, and it is sometimes seen as essential to the fulfillment of our highest potential as human being. Creativity can be defined and perceived as having the ability or power to create or produce any kind of works which is characterised by originality and, expressiveness from the originality of thoughts. We are clearly focused to setting up discourses on necessities of creative development to enhance the nation's creative economy that correlates to the future success in all kinds of creative-based careers, creative ability, and the future development of the creative industry.

Creative development in the work of art and music may comprise of two prominent factors, aspects of creative critical thinking and, stylistic and artistic innovations. These factors are perceptible to be seen as a distinction to unleash one's talent and adapt to unforeseen change to flourish the creative art industry. The deeper their relationship with music, and with their own unique creative expression, the more likely they'll be able to transform the work of art and music into a product or a master-piece, fulfilling and resonating their human experiences. As pointed out by Blacking (1995): "the value of music is inseparable from its value as an expression of human experience. Thus the world of music is a world of human experiences'.

Creativity makes us become more adaptable and resourceful. Beyond creative expressions, adding music to movement for example, dances or sports, can increase both our physical endurance and intelligence. Combining other forms of creative expression for example collaborating music with films or other forms of static and moving images, or recognizing musical nature inherent in those forms, can open us up to a whole new range of creative ideas. In the work of art, new creative ideas may move and relocate the work of art and music to new heights and dimensions of aesthetic and commercial appreciations. The art for economy as it may be referred, may repositions significations of art products in the mainstream of the nation's creative industry that has been seen as prominent in generating the nation's economy.

In the spheres of music, the music business is an entity serving to enable and support the creation of musical products for example records, videos, concerts and published musical works, for the commercial exploitation of the copyrights embodied in those products. The notion of creativity in music works or product is eminent, probably a fascination which encompasses to attaining creative and commercial preference results. Commercial preference in this case, can be perceived as obligations to commercialization characteristics in which aspects of quality, creativity, expressions and aesthetic are significantly illustrated in the work of art. In the course of productions, conceptions of 'fashion', stylistic design, or to some extent, sound and acoustics impressions as well as other creative concept are artistically and aesthetically observed.

In this context, music instrument craftsmanship, whereas traditional or modern instruments has been seen as a creative product development with associative element of the arts, science and engineering. This is 
illustrated in the instrument design and from other artistic processes, to measuring of sound and acoustics. The presence of artistic and commercial value properties are created to induce the product to be seen as a convincing creative commodity that can fascinate music consumers. On another note, as has been observed, music instrument making in Malaysia is mostly operated on a cottage industry concept. Similar activities can also be seen in some places in Indonesia. However, it's noteworthy to mention that music instrument products created by cottage industry are often unique and distinctive given the fact that they are usually not mass-produced. This is attributable to the concept of cottage industry where the creation of product is home-based, rather than factory-based. Cottage industry defines itself as a loosely organized, usually small-scale industry carried on at home by family members using their own equipment. It is a business system in which goods are produced at home for commercial use or sale.

This preliminary report therefore analyses and highlights some aspects of creativity and innovations in music instrument making, as a cottage industry activity, in pursuit of the future and growth of music business and industry. Some of the works has been observed and seen at locations of interest in local villages and at places of visits outside Malaysia. The analysis too discusses some insights on business opportunities, anticipating in drawing interests and curiosities among Malaysians or business institutions, in the world of Malaysian music business.
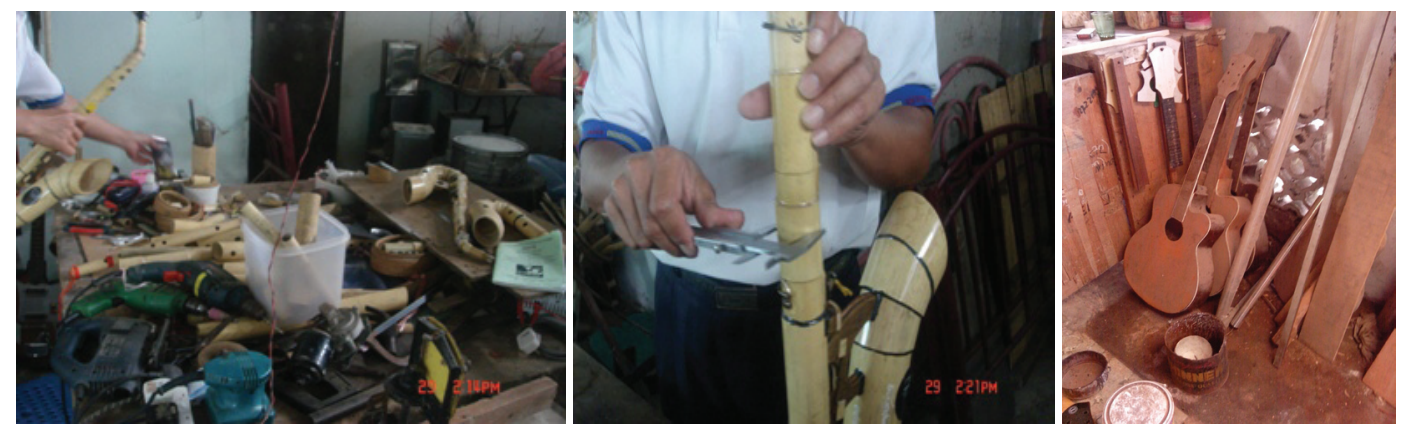

Figure 1: Traditional music instrument making tools and workshops

\subsection{Music Instrument Making - The Art and Aesthetics}

As one would have anticipated that, new musical patterns or groups may occur out of cultural process, the establishment of keroncong ensemble for example in Indonesia has been observed as a result of creativity and innovative of the people. The introduction of keroncong music in Indonesia as argued by Kornhauser (1978) which has been seen as results of cultural processes from activities of Portuguese seafarers and settlers in Tugu, Batavia, in the middle of 17th century, has placed Keroncong successfully 
as Indonesian ensemble despite debates by keroncong enthusiasts and academicians. The creative ability of the people to fashion keroncong's 'musical texture' and instruments along the line of Sundanese gamelan rhythmic texture, resulted keroncong as a distinctive ensemble of the Indonesians. As has been observed, new instruments were created to accommodate keroncong in defining a signature of it. 'Cuk' and 'Cak' performance style which is the central to patterns of keroncong distinctive Sundanese gamelan aesthetic interlocking rhythm, were created and fashioned to the performance centricity with improved organology and organographical features to that of Hawaiian ukulele. These instruments were carefully constructed to produce the desired tone characters and colours as they produce musical impact on the 'sound characters' of the ensemble. In this case, crafting of music instrument to achieve the essence of art, notably requires high level of craftsmanship in the creative mastery process. Transgressions to western instrument design may occur however, distinctive instrumental tonal values are intrinsic factors to be reconsidered.
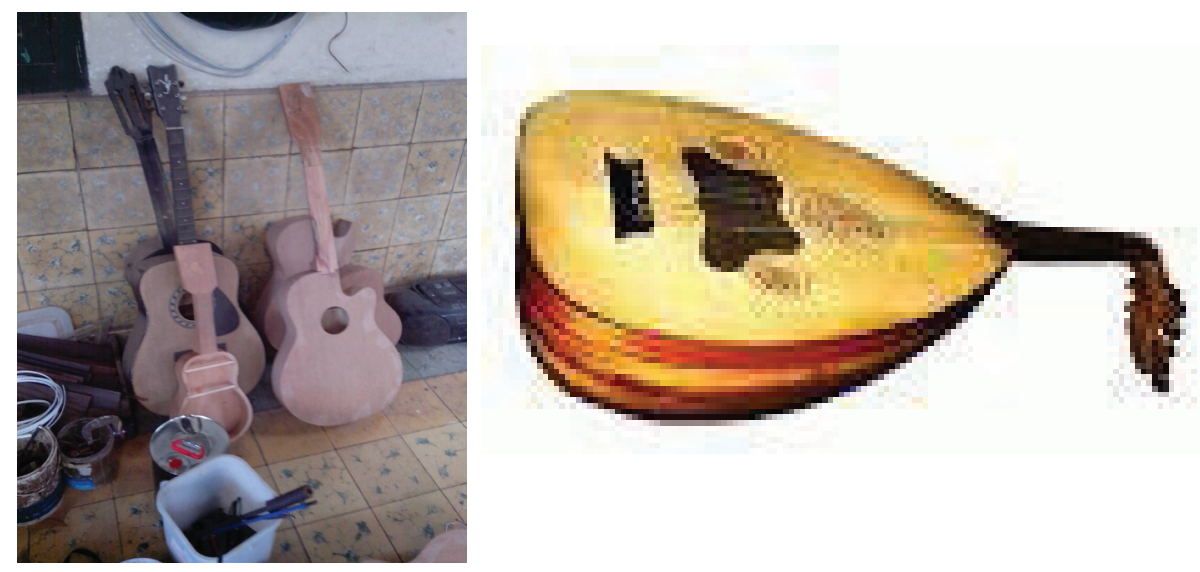

Figure 2: Cuk/Cak in the making and Rounded - belly Gambus

Spectrums of music instrument making today showsthat music instruments are either created or reconstructed. Cuk and Cak of the keroncong ensemble have been seen as reconstructions of western ukulele, while Johore's gambus has its roots from Arab-Persian 'Oud' or the European 'lute'. Gambus is now being actively produced in the state of Johore. A similar instrument identical to gambus, the ovation guitar was introduced to the market in the early 1980s. The guitar has a gambus 'rounded belly' which produces good mellow tones with rich bass sound. On another note, bamboo flutes are widely produced by traditional musicians especially in rural areas. These flutes produce different sound and tone colour, attributable, to the art of making the instruments. However it is different physically, production of sound or tone of an instrument forms part of instrument's aesthetic values. A wailing Turkish flute may set a person's 
emotion, or pounding of Chinese or Korean drum or the rebana ubi of the Malays may invoke the spirit of gallantry and heroism. These semiotical centricities are instrumental aesthetics communicating the music with the environment and surroundings.

Creating music instruments or product is perceived as a journey of a thousand miles. The aspect of art and aesthetic is an 'intact' factor that require due considerations. An observation at the world music museum in Poland suggests that, in the early days, the making of instrument, a violin or a viola for example requires creative mastery of craftsmanship. Apart from tonal production centricities, stylistic design and decorations on the instrument are observed as enthralling components constituting to the values of instrumental aesthetics. The artistic work demonstrates comprehension of cultural appreciation among the people and adds value to the community's musical system.

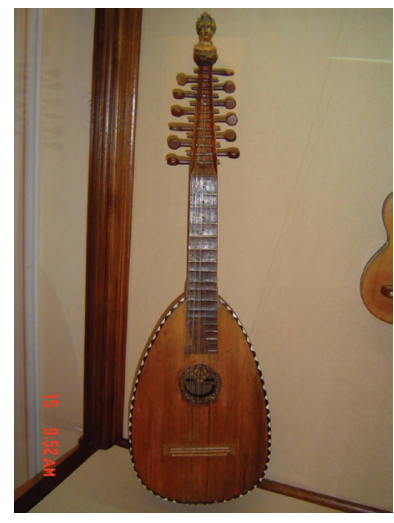

Figure 3: 12 -peg Lute

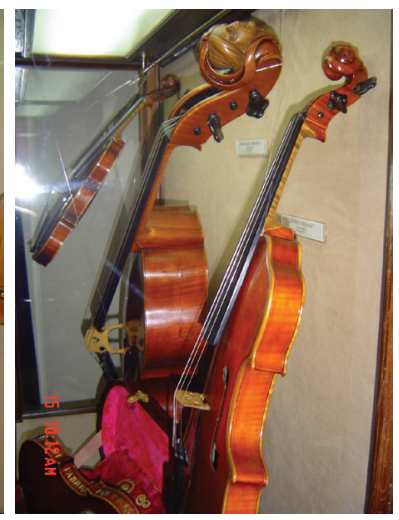

Figure 4: Decorated Violin neck

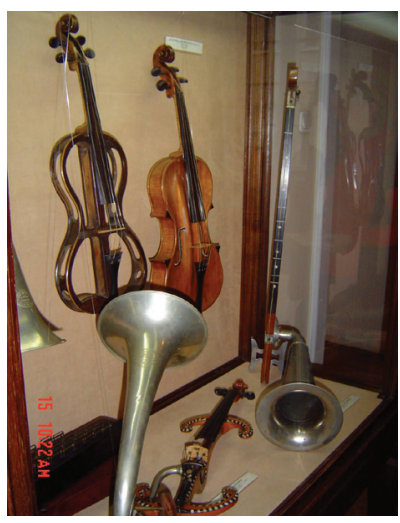

Figure 5: Creative Design

Similar work of craftsmanship can be found in the creative making of an aerophonic instrument in Sabah. Artistically crafted, the instrument called 'somporing' has characteristics and physical features of a western saxophone. Somporing is observed as an ethnic-contemporary music instrument. It is made of bamboo from selected species either 'rugading' or 'kuning' from the forest in Tambunan villages. It is traditionally and conventionally constructed in small huts in the absence of computer applications and devices. DIY tools such as saw, spanners, pliers, rulers, glues, cutters and knives, are predominantly important in the process. These are essential tools to produce 20 separate parts of somporing. Prior to cutting process, a diagram resembling western saxophone is sketched and drawn on to a wooden plank with precise measurement written on it. 20 separate units are identified and each unit or bamboo cuts is carefully measured using rulers and calipers. These parts are then systematically attached and glued together to be assembled as one instrument known as somporing.

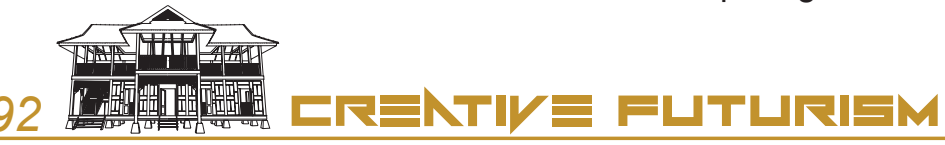




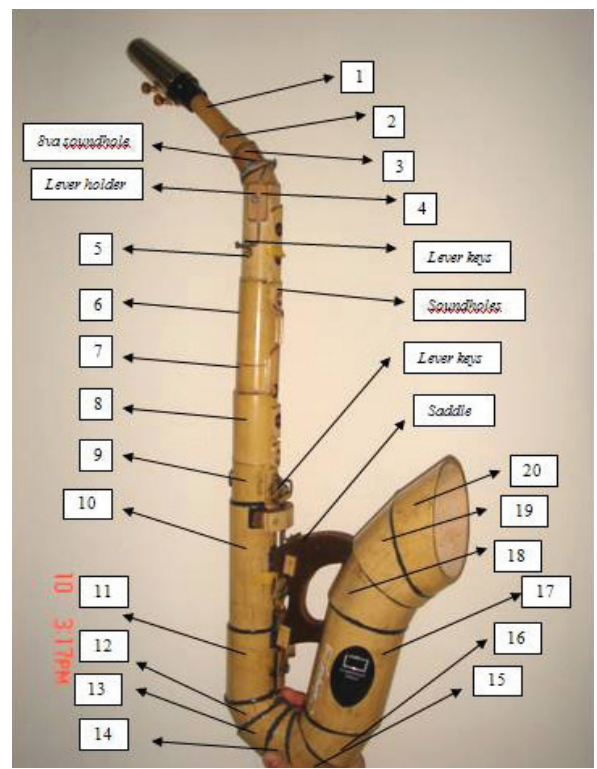

Figure 6: 20 bamboo parts
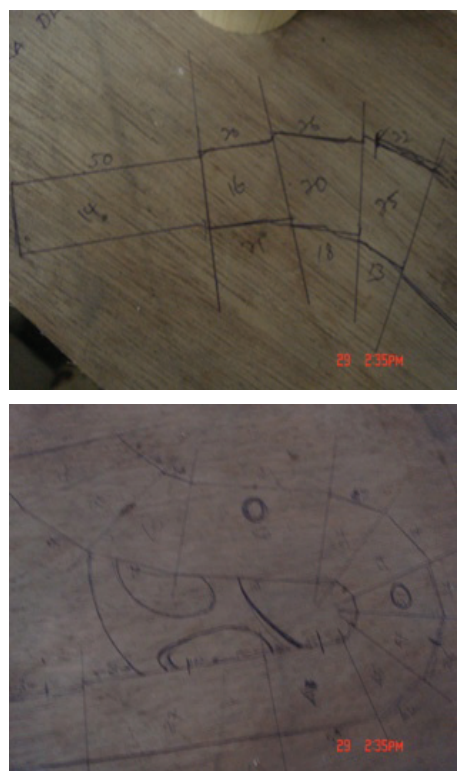

Figure 7: Sketches on planks

The making of somporing illustrates the mastery of craftsmanship particularly in constructions of the 'curve' and the 'horn'. The curve functions to connect the main body and the 'horn'. It is an assembled unit of five (5) bamboo parts which is carefully measured to the exact calculation of the required component. To create the 'curve', aspects of mathematical calculations are indefinitely required to achieve the desired size and design. Each part resembles the shape of a ring and has bigger diameter. The concept of ringshaped bamboo parts and gradual increase in diameter of each 'ring' enable each unit to fit into one another, forming the 'curve' that securely connects to the horn.
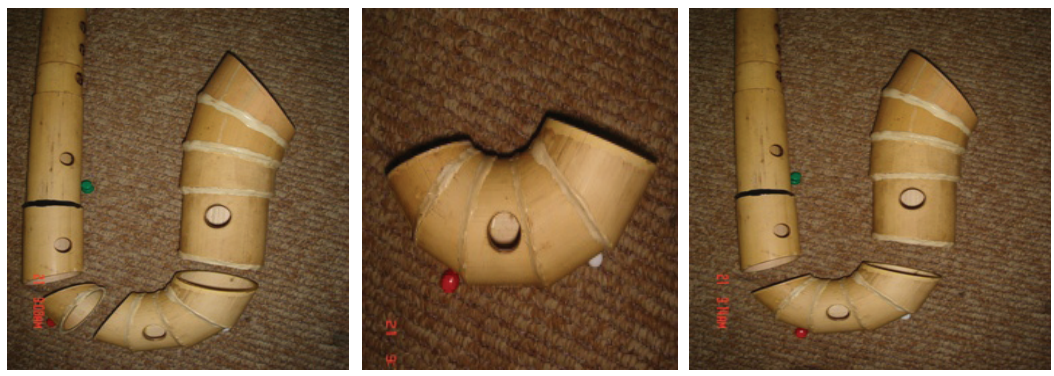

Figure 8: The curve dismantled unit curve bridging the horn 
Relatively, creative construction of somporing's horn or bell requires a definitive imagination of Sabah's flora called 'periuk kera' or its scientific terminology, nepenthes mirabilis. As the craftman asserts, the idea to design the horn is very much based upon Sabah's flora. This assembled section comprise of four (4) different measured units, a combination of cylindrical and ring-shaped units, to ensure a 'vertically projected horn' as is illustrated in nepenthes mirabilis. However unique the somporing is, it has proven that the tone colour and production of the instrument sound silky dark tones on low notes but bright, edgy and sparkling on the high notes. The tones sounded better coarse quality with soft edgy sounds, perhaps attributable to the source of nature in its construction, that is, the bamboo.

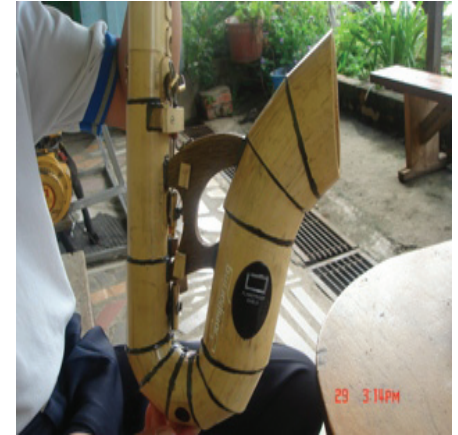

Figure 9: The horn /bell

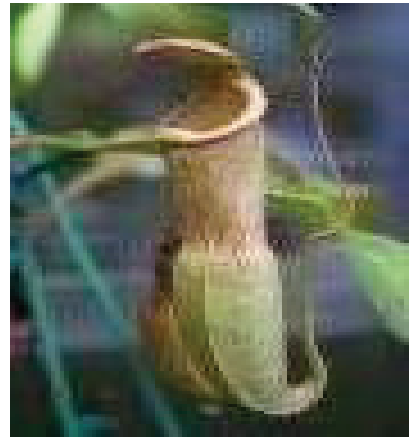

Figure 10: Nepenthes mirabilis

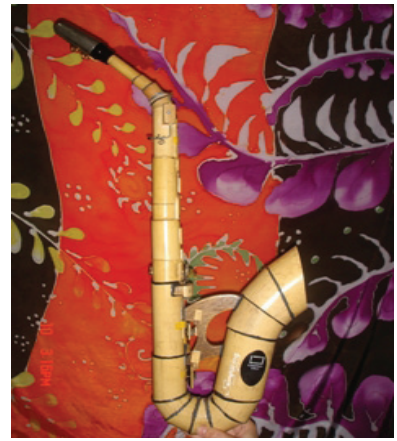

Figure 11: Assembled somporing

\subsection{The Cottage Industry - Creativity vs Commerce}

Evidently, creative music instrument craftsmanship produces artistic results with potential values for commercialization. A home-made cuk or cak, or an acoustic guitar is estimated to be at RM100-RM700 per unit, a rebana or singled-face drum from the Kelantan workshops approximately at RM300 per unit. In fact, it is noted that somporing's price tag has reached RM1000 possibly of the unique features and aesthetic considerations. In Indonesia, a set of home-made gamelan is estimated to be within the values of RM30,000- RM40,000. Evidently, cottage industry music business appears to be rewarding in the context to, alleviating the people's economy by way of producing creative work, despite accomplishment of productions commonly on a small scale business concept. Some of the businesses are aided by related authorities while others survived in isolation. The homes and huts are production factories while calipers, pliers and scrapers are the technology. Generally, activation for productions in this business sector will be triggered by or upon a specific demand or request. 
An observation in Solo, Indonesia, shows an artist creatively crafted guitar making activities in their homes applying traditional technology with conventional DIY tools, and in the absence of computer applications and devices. Initial design of the guitar structures is passionately sketched on to lengths of papers or on to the wood for quick reference, and the work begins. Although traditional kit and tools are prominent in this process, nevertheless the work of art has remarkable merit, and interestingly to note that, these custommade instruments, ironically produces well-crafted quality products. As pointed out by the informant who confesses that 'the human touch on every inch or part of the instrument structure is being felt by the hands, and this is a passionate matter to deal with when making an instrument'. Undoubtedly, his confessions have been seen as justifying the fact to comprehend that custom-made music instruments have better market value to that of factory fabricated products, in lieu of the fine work and aesthetic finishing that exist in the making of the instrument.

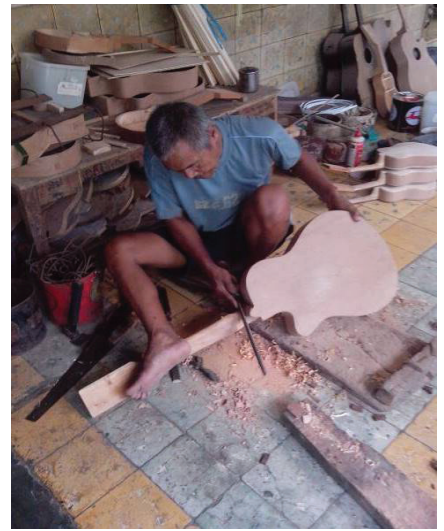

Figure 12: Neck sketches

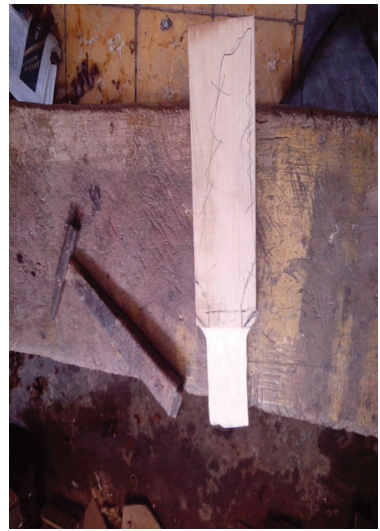

Figure 13: Designing the neck

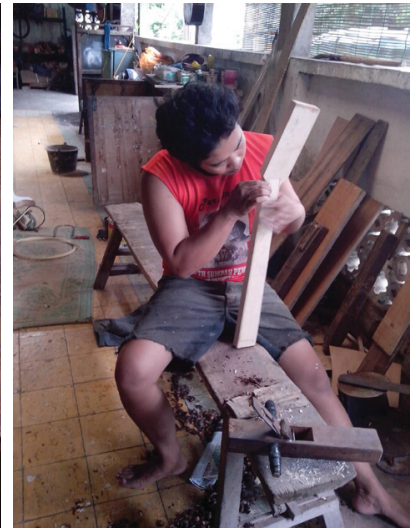

Figure 14: Shaping the curves

Application of traditional technology in music instrument making creates the feeling of tradition, and expresses pride in one's culture. Beyond the cottage industrial concept of sustaining the village's economy, Thebérge (1999) however points out that music-making has been seen as a form of entertainment or a leisure ethic that has become one of the more enduring ideological and economic conflicts for the musical instrument trade. In view of this, the concept of leisure ethic activities or a form of entertainment as argued by Theberge probably can be seen as factors mitigating senses of creativity and innovations among the artist. 
In the Malaysian scenario, the cottage industry in music instrument making is noticeable active in the 1980s. Angklung, gamelan instruments, Malay percussive single and double-faced drum and cak lempong were actively produced in the Javanese community villages in Sabak Bernam and Banting, Selangor, in Terengganu, Kelantan and in Johore led by the late Pak Margono Sitir and Pak Rubeon. However at present situation, the making of some of these instruments has shown evidence of failures and discouragement attributable to factors of depleting natural resources, insufficient knowledge in instrument making technology, passive art appreciators and other financial, economic and socio-cultural factors. As a result, these instruments were imported from neighbouring country, Indonesia, which had successfully produce good and high quality music instruments despite the cottage industry concept. Much of the instruments for example gamelan sets and angklungs, the bamboo-rattled instruments are exported to countries including Malaysia. The making of gamelan sets from kuningan metal in Solo, sets the standard of gamelan quality in Malaysia particularly to end users from among the higher learning institutions, schools and some government agencies. Relatively, the making of angklung instruments at Saung Pak Udjo, in Bandung has been observed as a thriving cottage industry in music business attributable to business concept of, instrument making and performance tutoring at the precinct. In view of this, cottage business in music has made Bandung a must-visit destination where tourist or travellers may observe the process of angklung instrument making and learning the ensemble performance techniques at the same time.

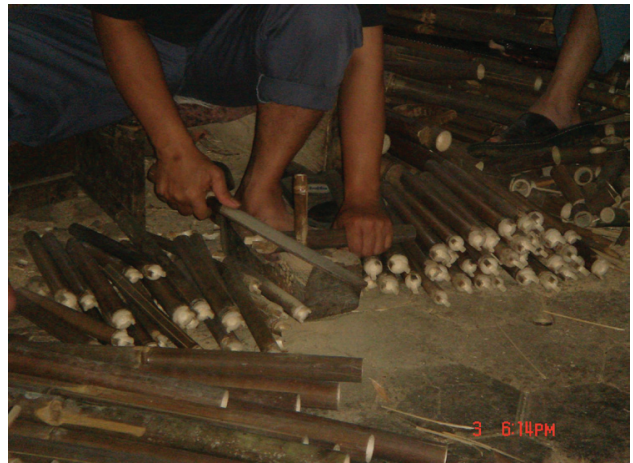

Figure 15: Angklung at Saung Udjo, Bandung

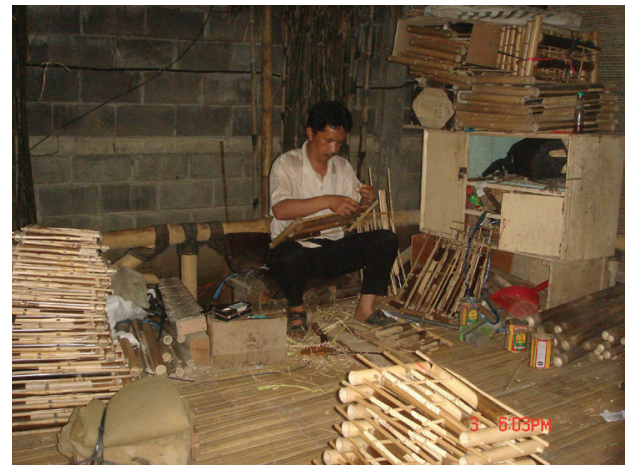

Figure 16: Scrapping the sharp edges

The need for music instrument has been observed as in continuous demand as music is consumed by people from all classes of life, status and economy. As has been said, music instrument making in Malaysia has been seen as a passive activity in the industry despite the amount generated by the creative industry in 2012. Much of the modern instruments available in the outlets for example guitar have been imported stuff with the exception of few traditional instruments of Malay origin. A survey in 2011 shows that, music distributors and retail outlets have the tendency and inclinations to display nonbranded guitars on the shelf as compared to branded guitars for a specific purpose. One has to believe 
that most of the buyers are middle-class group or blue collar workers, who tended to affordable but quality products. As a result, guitars from China, Korea and the Philippines began to flock the showrooms with competitive prices. On another note, retailing outlets, distributors or music outlets in the country distribute music instruments from abroad, Japan, UK or US with signature brands for example Fender, Ibanez, Gibson, Colt however, with the advent of China as the new economy power in the world, manufacturing of music instruments has shifted to China with similar brand, amidst quality ambiguities. These products dominate the market, and are comparatively cheap and affordable as compared to original fabrications. As the purchasing power being dominated by the consumers from mediocre group or class, the made-inChina product apparently acquire bigger market share. Evidence shows that, a leading music distributing in Damansara, Kuala Lumpur, who at the earlier stage championing and distributes famous Japanese brands or the US products, has finally shifted to distributing the lesser quality products from China. This issue explains the shifting patterns of music consumption among the people. The availability of affordable products plus the growth of popular culture particularly of popular music, has forced the market to open its door to competitive yet affordable music instruments. This demand for music instruments clarifies the results of the rise of popular music appreciation in this century following the advancement of technology in music dissemination through U-Tubes and other means in social media.

\subsection{Summary}

This preliminary work has substantially gathered invaluable facts and evidence in the context of accomplishing the work of art and music, and its association to the development of cottage business in music instrument making. It is pleasant to note that, aspects of musical legacy preservation have always been nurtured, cultivated and cherished by the people however, continuous manifestations and cultural expressions of people are observed and perceived as a creative process complementing to factors of 'continuity and change' in cultural and musical system. In pursuit to generate the creative economy, some activities of art in trade and economy is essential to alleviate the nations creative industry revenue, and to aggravate productions of creative products with significant values of expressions and aesthetics. Music instrument making has the potentials however in Malaysia, it has been noticed as a passive activity comparable to some countries in this region. On the contrary, the growth of music instrument making business in China, Indonesia and Korea has made these countries in the frontier of guitar distribution in Malaysia, while the Indonesians dominates traditional instrument market.

The absence of Malaysian music products or Malaysian brand on Malaysian retailing outlets deserves due thoughts and deliberations, perhaps reviewing the National Music Industry Policy or the Creative Industry Policy led by Ministry of Communications and Multimedia. Initial observations may suggest that the education sector to perform on a critical role to sustaining and enhancement of entrepreneurial tradition and practice among students. Some areas of curriculum design may have the extensions to entrepreneurial and specific business component. At the present situation, music studies at tertiary levels incorporate components of performance, music essentials, the theory, aural skills, harmony, arranging, 
perhaps some modules on music technology and business. These are conventional modules which enable placement of graduates in the challenging music marketplace at executive level instead of entrepreneurial needs. Aspects of music entrepreneurship particularly in the areas of music instrument making have yet to be embraced. In contrast, the higher learning institutions in the west for example Poznan Music Academy, Poland, introduces music instrument making or music instrument engineering modules as part of the music business module, guided by qualified lecturers and professional craftsman. Traditional and computer-based technology applications are applied in the making process. Computer software and devices are used to capture sound waves, sound acoustics and frequencies ensuring production of good instrument tones. Sounds and acoustics are well measured. Notably, Europe produces abundant wood products for instrument making for example Spruce, Maple, Mahogany, enabling the students to fabricate and produce music instruments for example, violin, violas and cellos. Music instrument making modules in Poznan has been seen as a process to creating graduates with diverse and competitive quality in music studies embracing spectrums of performance, technology and business.

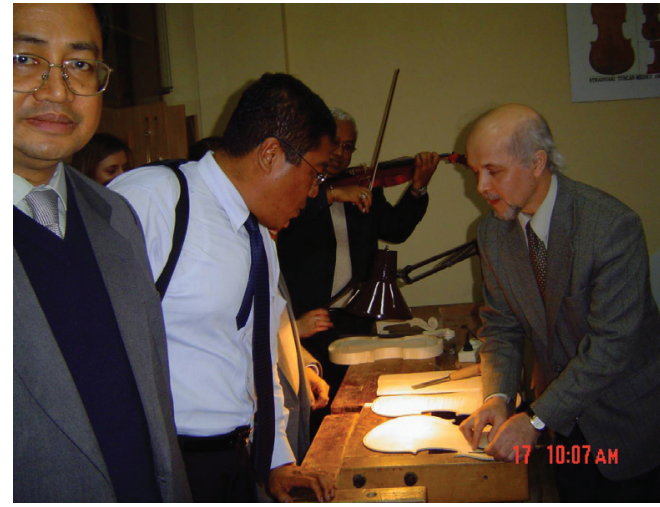

Figure 17: Writer observing violin frames

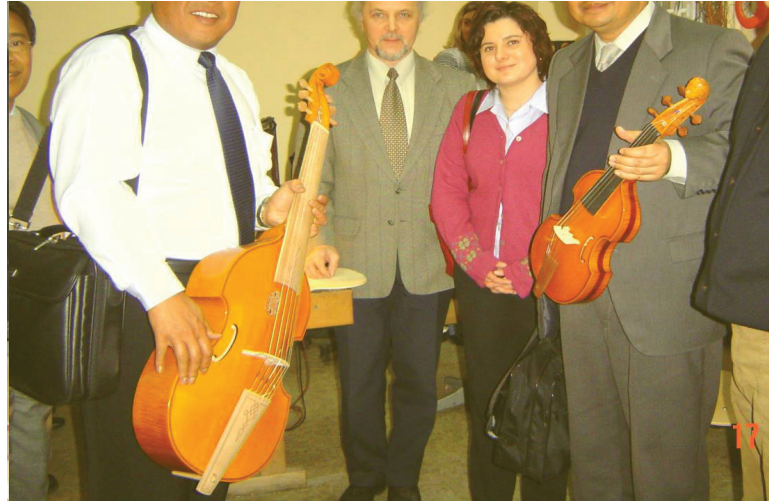

Figure 18: 'Made in Poznan' viola and cello

In this context, the trends in the UK and Poland may suggest Malaysian higher learning institutions to embark on music instrument making modules and programs. Malaysia produces good quality woods from local forest, Chengal, Meranti, Nangka, Seraya which can be experimented on by wood specialists for suitability to guitar making and other wood-based music instrument products. Lessons from the craft to art, from creativity to commerce and from pliers to computers should be introduced, and instilled in the process to produce entrepreneurs from universities. The shift of study to business-based or productoriented based system in music programs should be regarded as a stigma of change and transformation which is in line with the aspirations of the nation to generate the development of the Malaysian creative industry. This is to produce Malaysian music instruments that would reflect images of professional music craftsmanship and the inspiring Malaysian creative music industry. On another note, the cottage industry 
entrepreneurs have been seen as creative and innovative in producing the work of art with highly valued aesthetics embedded in the mastery craftsmanship. One may suggest that the setting-up or inauguration of the Malaysian Music Village will help to stimulate productions of art and music works and this may create new initiatives to steer and alleviate the nation's music business. This investment should be perceived as advocating and instituting the development of music business from cottage business to commercial business enterprises.

\section{References}

Blacking, J. 1995. Music, Culture and Experience. The University of Chicago press.

Stokes, M. 1994. Ethnicity, Identity and Music : The Musical Construction of Place. Berg publishers.

Nik Mustapha Nik Mohd Salleh, 2009. Alat Muzik Tradisional dalam Masyarakat Melayu di Malaysia, Kementerian, Kebudayaan, Kesenian dan Pelancongan.

Kornhauser, B. In defence of kroncong, in Kartomi, M. (ed) 1978. Studies in Indonesian Music. Monash University, Melbourne.

Théberge, P. 1999. Any Sound You Can Imagine: Making Music/Consuming Technology. University Press of New England.

DiMaggio, P and Useem, M. An Example of Evaluation Research as a Cottage Industry: The Technical Quality and Impact of Arts Audience Studies in Sociological Methods \& Research, August 1978; vol 7. Sage Publications 